\title{
組織培食法ニョルまくろふお一げんノ淋菌喰 燼作用二就テ
}

\author{
第 1 篇 蒙兔脾藏まくろふあーげんノ淋菌喰燼作用 \\ 尔都帝國大學繁學部徽生物學教宝（主任 木村教授）
}

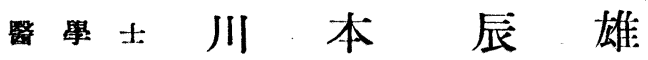

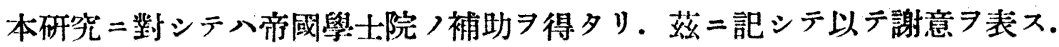

\section{【内容抄 錄】}

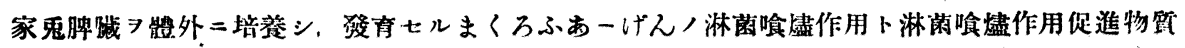
在生ト, 關保习检ンタリ.

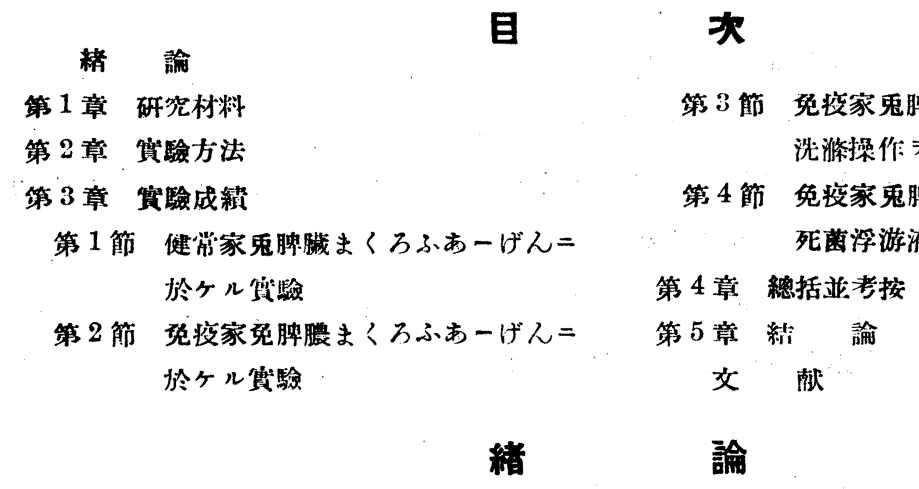

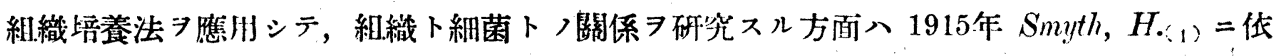

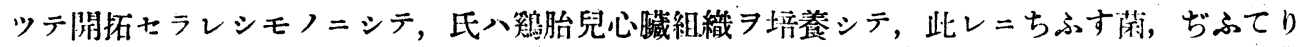

一菌, ぷそいどぢふてり一菌, 大腸菌等ヨ接種シ，培養組織紐胞卜紐菌トノ關係习研索シテ 以ツテ.本法〉利用價值 7 高メタリ。

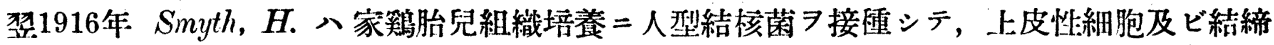
織性細胞ガ良タ結核菌习喰熅スルコト及ビ新種細胞ガ形成セラレル事习認メタ.ソノ後相次

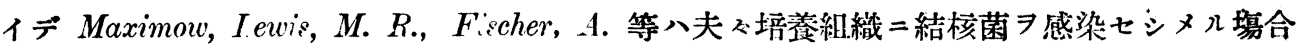

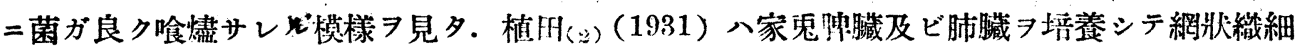
胞並ビ二肺胞上皮性細胞ガ結㤥菌

次二, 結核菌以外入細菌つ喰燼現象二就イテへ, Jones u. Rous (1917) 八造結締織細胞八

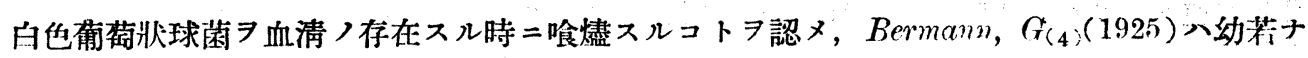
ル骨䯕性細胞ガ葡萄狀球菌ヨ喰スル状况习觀察シテ居ル。 


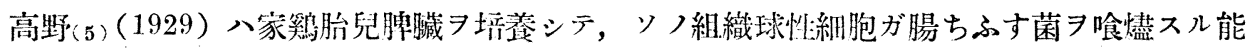
力八, 腸ちふす菌わくちん或八ちふすとくちげんヨ培地二附加スル事ニョツテ著シク旺盛二 ナリ，且ツ 1 㑉ノ細胞中二攝取七ラレタルちふす菌ノ平均數モ著シク大デアルコトヨ報告シ テイル。

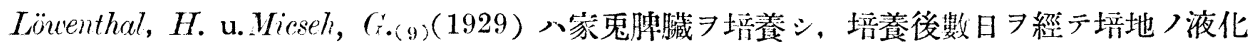

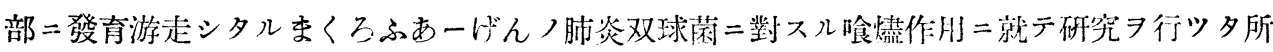

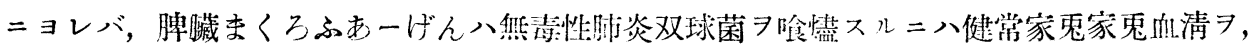

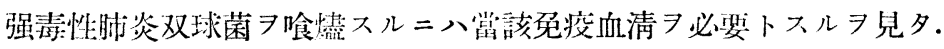

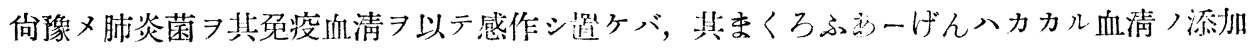

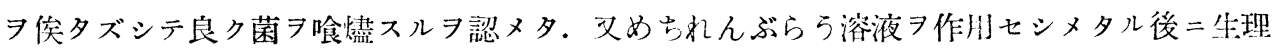
的食監水 ろふあーげん二喰衤セラレタル像フ認メタ。

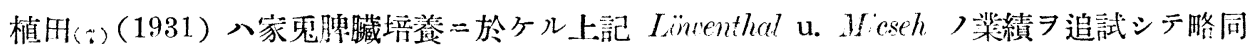
樣〉成績

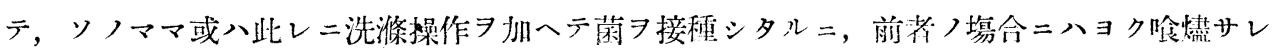

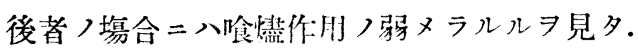

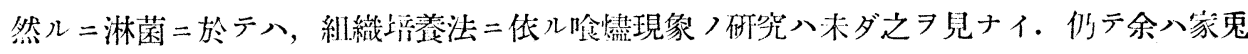
脾臟 報肯セント欲ス。

\section{第 1 章 研 究材 料}

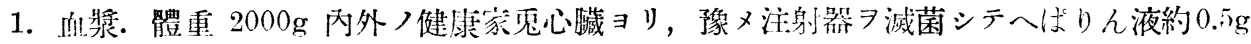

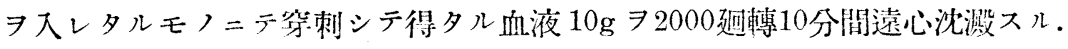

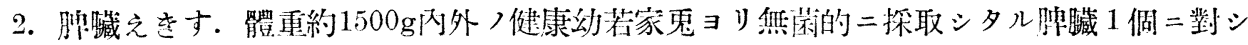

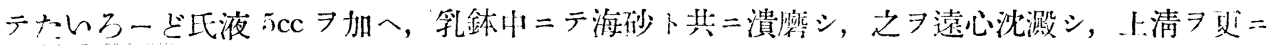
たいろービ氏液ニテ5倍二稀釋ス。

3. 細織. 幼萑家鬼虾臟.

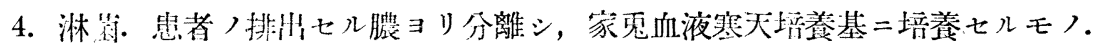

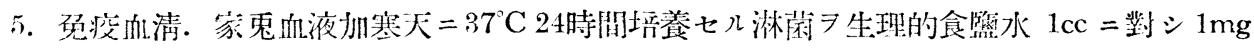

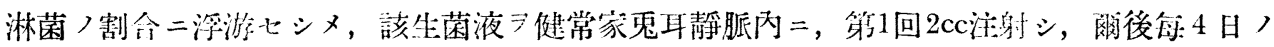

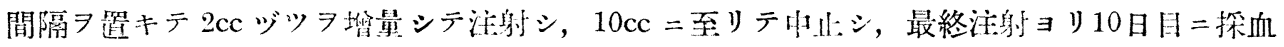

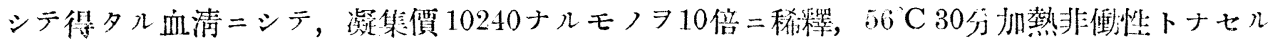


モ).

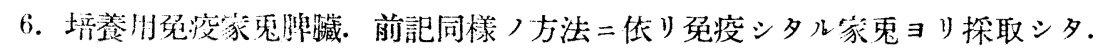

\section{第 2 章 實 驗 甫 羷}

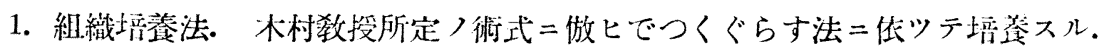

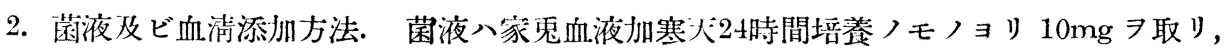
$20 \mathrm{cc}$ りん゙る氏液二浮游セシメ, 遠心器ニテ 3 回洗淮シテ同量トナ七ルモノ (死菌

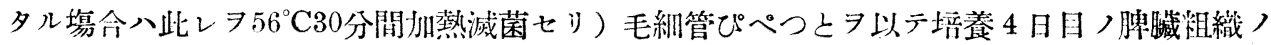
ぷンておりーぜヨ起シタル部分二靜カニ 1 滴ヨ添加シタ. 血清モ同栐ニシテ毛細管ぴペつと ヨリ1㵜习添加シタ.

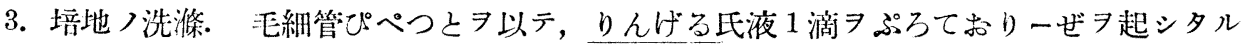

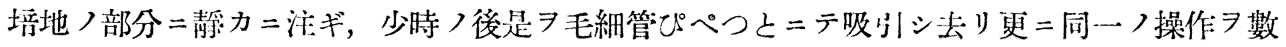
回反覆スル。

4. 檢鏡. 菌液涯加後 5 時間 7 經タル時 $2 \%$ シ，24時間水洗シテ後比較的稀薄ナルぎーむざ液（蒸溜水 $100 \mathrm{cc}=$ 細目つぴぺつとニテ 40 滴 ぎーむざ氏液フ加へタルモノ) =テ 24 時間染色シ，水洗スルコト 3 時間ニシテ，標本八孵 卵器內或ハソノママ室內二放造シテ乾カシタルモノラ檢鏡=供シタ.

\section{第 3 章 實 驗 成 績}

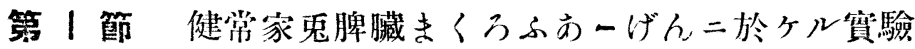

1. 淋菌浮游液ノミヨ添牒シタル塲命.

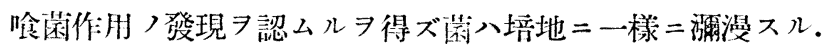

2. 淋菌浮游液卜共 $=$ 新蘚健康血清 7 添加シタル塲合.

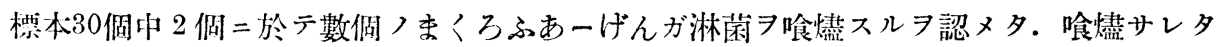
ル阙數入ら乃至 10 倜デアル。

3. 淋菌浮淤液及ビ冤疫血清习添加七儿塲合.

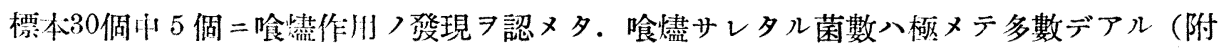
回參照).

第 2 篩 苑疫家鬼脾藏まくろふむーげん

1. 淋菌浮游液, ミ添加七儿塲合. 標本30倜中5倜二喰䟧作川）發現习認メタ。

2. 淋菌浮游液卜共 $=$ 宏疫血清 7 加へタル塲合.

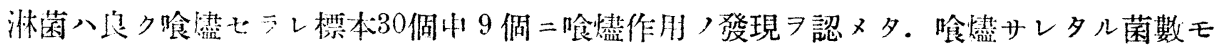


多數デアル。

3. 洗滌操作ヨ施シテ淋菌浮游液习源加セル塲合.

喰櫵作用ノ發現八稀デアル。

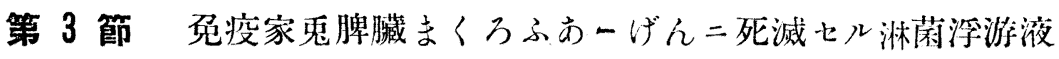
习添加セル㙁合

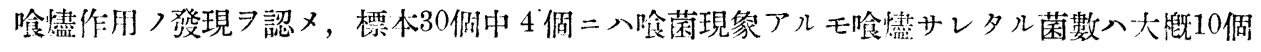

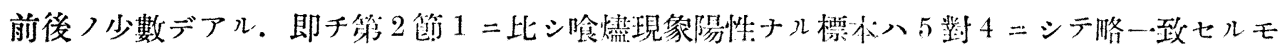
被喰燼菌數入楛ダシク少數ナルラ知ル。

\section{第 4 章 總括並二考 按}

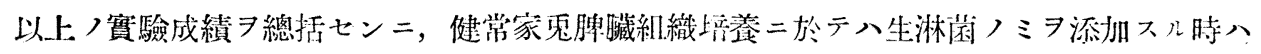
淋藏八同組織〉まくろふあーげん二依ツテ喰㥺七ラレル事ナク，是レ二免将血清ヨ源加スル

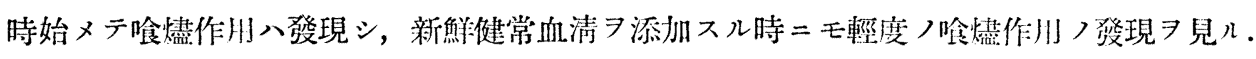

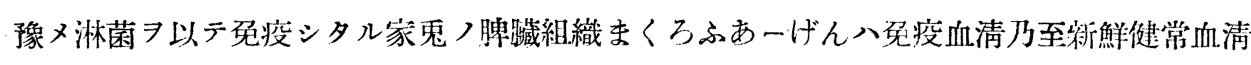

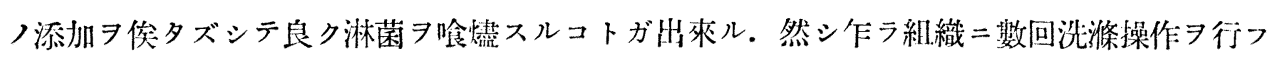

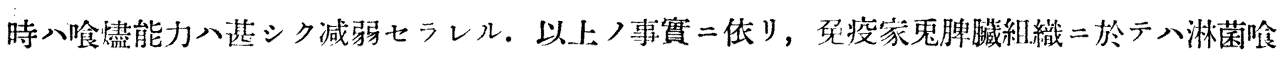

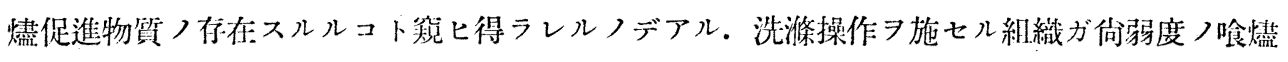

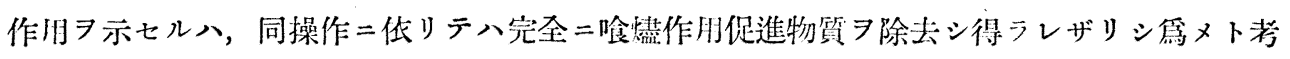
ヘラレル。

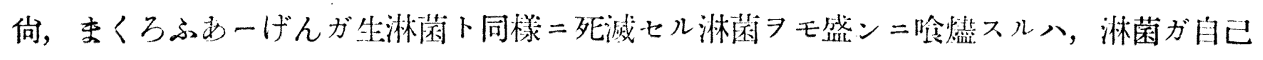

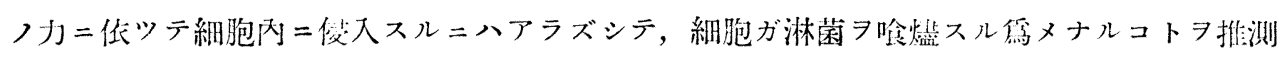

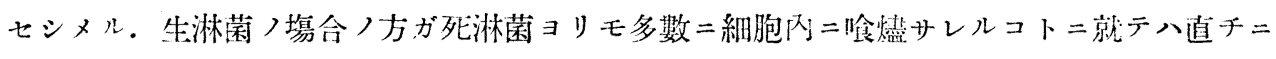

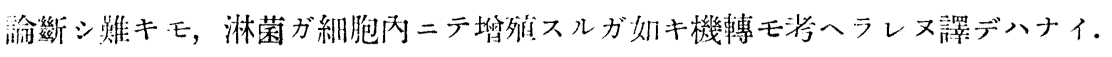

\section{結論}

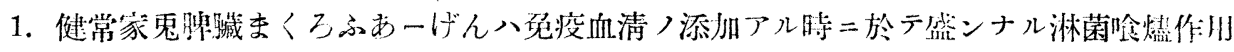

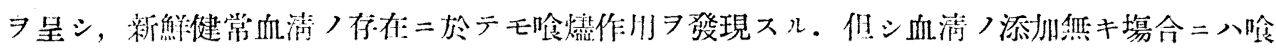
㸁現象ヨ認メナイ。

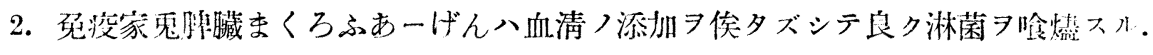

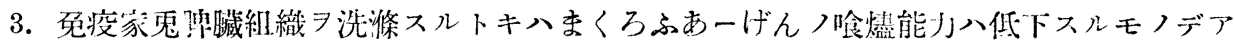

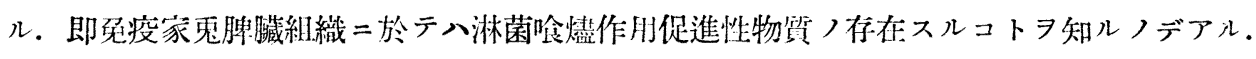

4. 淋菌八自働的二まくろふあーげん冈二浸入スルモノデハナク，細胞內ニアル淋菌八呤 烧作师二肉ルコト二推察スルコトガ出來ル。 


\begin{tabular}{l|l|l|l} 
川 & 本 & 辰 & 雄
\end{tabular}

擱筆スル

\section{文献}

1) Smyth, H. F., The reaction between bacteria and animal tissues under condition of artifical cultivation. J. emp, med. 21, 103. (1915). The influence of bacteria upon the development of tissuse in vitro. Zbl. Bakt. I. Abt. Org. 76, 12. (1915). The reactions betweeu bacteria and animal tissues etc. I. The action of bacterial Vaccines on tissues cultures in vitro. J. exp. Med. 23, 295. (1916). 2) 植田, 日本微生物學将理學雜誌, 第25 卷, 第10號. 3) Jones, F.S. u. Rous, P., The Phagotitic Power of connective tissue cells. J. exp. Med 25, 199 (1917). 4) Bermann, G., Ueber die Jnfektion von Knochenmarkskulturen. Arch.t. exp. Zellforsdg. 1, 392. (1925). 5 ) 高野, 組螕培養法二依儿

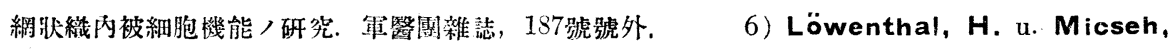
G. Phagocytoseversuche mit Milzmakrophagen in gewebekultur. Zsch. f. Hyg. 110, 150. (1929). 7) 植田, 家鬼脾臟まくろふあ一げん八肺炎菌喰蛊作用二就テ，日本微生物學病理

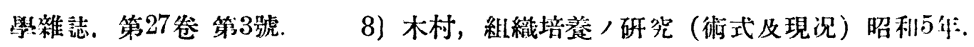




\section{附 圖 說 明}

䉆 昆

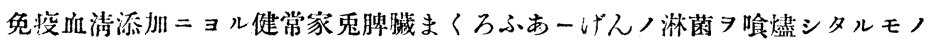

a. まくろふあーげん.

b. 淋菌聚落.

畫訚同上. 
川本論交附圖
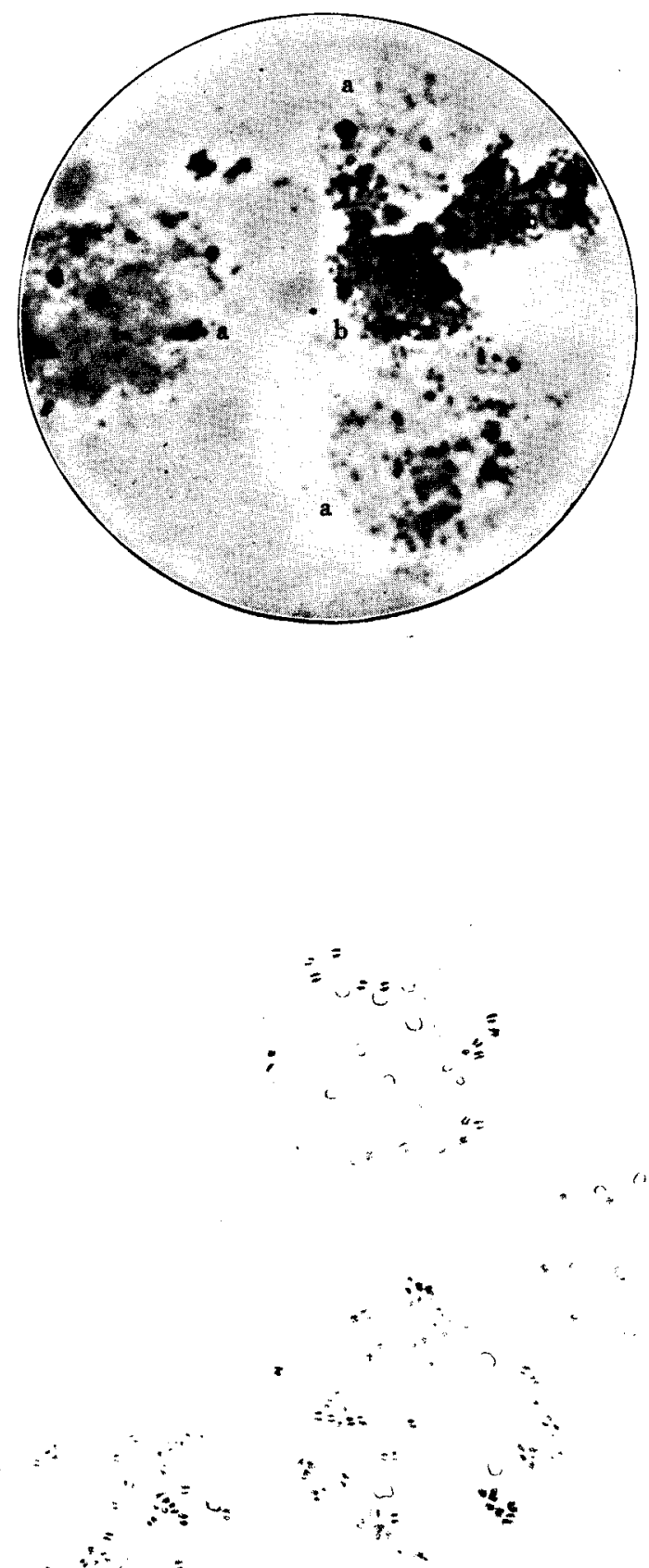

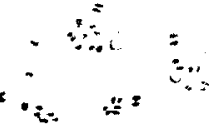

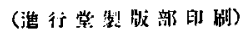

